\title{
REDEFINISI KEMATIAN
}

\author{
Michelle Clara $^{1)}$, Franky Liauw ${ }^{2)}$ \\ 1)Program Studi S1 Arsitektur Universitas Tarumanagara, micheclara97@gmail.com \\ 2)Program Studi S1 Arsitektur, Universitas Tarumanagara, frankyl@ft.untar.ac.id
}

\begin{abstract}
Abstrak
Kota adalah rekam jejak peradaban manusia dari waktu ke waktu dengan berbagai fenomena yang terjadi di dalamnya. Manusia kerap menandai kota dengan berbagai kisah tentang penciptaan ruang-ruang yang dianggap mampu mendukung kelangsungan hidupnya. Akan tetapi, di tengah dinamika perkembangan zaman dan pertumbuhan generasi yang mendiami kota, manusia seolah melupakan salah satu entitas kehidupan yaitu kematian. Dalam beberapa dekade terakhir, kita kerap menghindari topik terkait kematian ini, sehingga tanpa disadari, aktivitas terkait kematian sesungguhnya telah mengelilingi kita. Rasa takut akan kematian telah meninggalkan tanda dari waktu ke waktu; generasi ke generasi; hingga akhirnya bertumbuh menjadi sebuah paradigma negatif di masyarakat. Penelitian ini bertujuan untuk menghadirkan revolusi pada kota melalui redefinisi keruangan arsitektur dalam mewadahi proses kematian secara positif di masyarakat. Metode dari penelitian ini, antara lain: pertama, melakukan studi literatur, penelusuran kasus-kasus kematian dengan berbagai kondisinya dari ahli yang menangani; kedua, melakukan pendekatan berbagai teori psikologi tentang persepsi, pengenalan diri, tahapan dalam menghadapi kematian, emosi, dan lainnya yang terkait; ketiga, menyusun program keruangan arsitektur dengan pendataan aktivitas dan skenario ruang. Melalui eksperimen, serta berlandaskan berbagai preseden yang sudah ada, diharapkan dapat diperoleh kriteria rancangan arsitektur yang dapat mempengaruhi persepsi dan emosi manusia, terutama bagi individu yang mendekati masa kematian, sehingga bersama dengan terapi, konsultasi, doa, atau bentuk penghiburan dari berbagai pihak, dapat menenangkan penderita, juga para keluarganya.
\end{abstract}

Kata Kunci: arsitektur; bahagia; kematian; proses; tenang

\begin{abstract}
The city is a track record of human civilization from time to time with various phenomena that occurs. Humans often mark cities with various stories about the creation of spaces that are considered capable of supporting their survival. However, in the midst of the dynamic era and the growth of generations that inhabits the city, humans seem to forget one of the life entities, namely death. In the past few decades, we often avoided topics related to death, so that unwittingly, activities related to death actually surround us. The fear of death has left a mark from time to time; generation to generation; until finally it grows into a negative paradigm in society. This research aims to bring a revolution to the city through the redefinition of architectural space in accommodating the process of death positively. The methods of this study include: first, conducting a literature study, tracing death cases with various conditions from experts handling; second, approaching various psychological theories about perception, selfrecognition, stages in facing death, emotions, and others related; third, compiling a spatial architecture program by elaborating activities data and space scenarios. Through experiments, and based on various precedents that already exist, it is expected to obtain an architectural design criteria that can affect human perceptions and emotions, especially for individuals who are approaching the death and dying, so that together with therapy, consultation, prayer, or a form of consolation from various parties, can soothe sufferers, also their families.
\end{abstract}

Keywords: architecture; death; happy; peaceful; process 


\section{PENDAHULUAN}

\section{Latar Belakang}

Sejak awal keberadaannya, manusia telah menciptakan ruang untuk mewadahi kelangsungan hidupnya baik secara individual maupun kelompok. Dengan menjadi saksi atas perubahan kota yang kian pesat, arsitektur perlu merekonstruksi dirinya dalam fenomena yang sedang berlangsung dengan mempelajari sejarah dan memprediksi masa depan. Namun, di tengah perubahan tersebut, manusia melupakan sebuah fenomena yang sesungguhnya menjadi sahabat akrab dari kehidupan yaitu kematian. Masyarakat kerap menghindari pembahasan terkait kematian selama beberapa dekade terakhir.

Kematian kerap dianggap sebagai momen kehilangan secara permanen bagi sebagian besar orang. Proses kematian pun kerap diiringi oleh rasa takut dan ketidaksiapan secara personal dan juga pada orang terkasih yang ditinggalkan. Namun, dengan rekonstruksi fungsi kognitif dan emosi seseorang dengan memori positif, persepsi tersebut dapat diminimalisir, sehingga proses menuju kematian akan dimaknai dengan cara yang berbeda.

Dalam beberapa dekade terakhir, tipologi arsitektur terkait kematian belum mengalami evolusi yang signifikan. Rumah sakit, pemakaman, dan krematorium telah menjadi contoh program arsitektur dalam mewadahi kematian secara fungsional. Seiring dengan bergantinya pemaknaan masyarakat terhadap kematian, arsitektur perlu meregenerasi diri dan meredefinisikan keruangan yang dapat mewadahi tidak hanya kematian saja, melainkan juga proses kematian. Dengan bertambahnya jangka hidup seseorang, dan meningkatnya penyakit yang mampu melakukan degenerasi, kita tengah berada dalam rentang waktu di mana kita akan menghadapi kematian secara besar-besaran.

Secara tidak sadar, kematian yang tengah dihindari sebagai topik pembahasan juga turut mengambil porsi dalam sebuah kota, di mana fungsi arsitektur terkait kematian telah mengelilingi keseharian kita. Kematian menjadi relevan pada hal medis dan institusi, di mana keruangan pun dibuat berdasarkan kedua hal tersebut. Apabila kita berpikir secara pragmatis, pengalaman individu dalam menghabiskan sisa hidupnya akan berlangsung di rumah sakit, dengan jaminan perawatan yang memadai. Namun, bila kita melihat dari segi humanis, bagaimanakah sesungguhnya arsitektur dapat mewadahi manusia untuk memaknai kematian pada era ini?

\section{Identifikasi Masalah}

Dari latar belakang tersebut, terdapat identifikasi masalah yang akan dijadikan bahan penelitian antara lain sebagai berikut:

a. Perkembangan arsitektur dalam mewadahi kematian di kota kurang mengalami evolusi dari segi makna dan fungsi

b. Paradigma masyarakat secara umum terkait kematian masih negatif dan berdampak pada pandangan dan kesiapan individu dalam menghadapi proses kematian

c. Belum ada reaksi spesifik dari arsitektur terkait program yang mampu mewadahi proses kematian

\section{Tujuan Penelitian}

Terdapat beberapa tujuan dalam proyek ini untuk bisa berfungsi secara maksimal dalam menjawab masalah yang diangkat sebagai berikut;

a. Menghadirkan program arsitektur yang interaktif dan positif dalam mewadahi proses kematian masyarakat di kota

b. Mendorong munculnya pengalaman positif terkait proses kematian pada masyarakat melalui program arsitektur yang diajukan

c. Membantu masyarakat dalam meredefinisikan kematian dan proses kematian secara positif 


\section{KAJIAN LITERATUR}

\section{Five Stages of Death and Dying (Kubler Ross \& David Kessler)}

Sebagai upaya mendalami proses kematian manusia yang menjadi fenomena utama dalam proyek ini, perlu dilakukan pemahaman mendasar terkait psikologi manusia dan tahapan psikologis yang dilalui dalam menghadapi kematian sebelum akhirnya menentukan program yang sesuai dan tepat guna atas fenomena tersebut. (Kubler-Ross \& Kessler, 2007). Penyangkalan adalah tahap pertama dari lima tahap dalam menghadapi kematian. Penyangkalan adalah mekanisme pertahanan diri atas situasi yang kurang bisa diterima di mana seseorang akan merasa dunianya menjadi tidak berarti dan melelahkan. Penyangkalan membantu kita mengatasi, melanjutkan kehidupan, dan mengatur perasaan sedih.

Tahapan kedua ialah kemarahan di mana tahap ini merupakan tahap penting dan normal dari proses penyembuhan. Diperlukan langkah yang tepat dalam mengungkapkan kemarahan, karena kemarahan tidak memiliki batas dan dapat mempengaruhi orang di sekitar kita. Untuk itu, kemarahan perlu diarahkan untuk menjadi jangkar dan memberikan kekuatan sementara dalam menghadapi kehilangan, karena kemarahan adalah refleksi dari intensitas cinta yang kita miliki.

Setelah melewati kedua tahapan di atas, kita memasuki tahap negosiasi dengan diri kita. Kecenderungan yang muncul ialah pemikiran bahwa seandainya kita dapat memutar waktu ke masa sebelum kita akan menghadapi kehilangan yang besar, kita dapat melakukan sesuatu atau pencegahan atas hal tersebut. Perasaan bersalah adalah sahabat akrab dari tahapan negosiasi diri ini. Melalui proses ini, kita dapat menemukan kesalahan dalam diri kita dan hal yang kita harapkan untuk terjadi.

Setelah melalui tahapan negosiasi diri, perhatian kita langsung beralih ke masa kini. Pada tahap ini, kita cenderung akan merasakan kekosongan sebagai awal dari kesedihan yang lebih dalam dari yang pernah kita bayangkan yaitu depresi. Penting untuk dipahami bahwa depresi ini bukan pertanda dari penyakit mental. Depresi adalah tahapan di mana kita menarik diri dari kehidupan dan berfokus pada diri sendiri. Jika kesedihan adalah proses penyembuhan, maka depresi adalah salah satu dari banyak langkah yang perlu dilakukan.

Kebanyakan orang tidak pernah merasa baik-baik saja ketika ditinggalkan atau meninggalkan orang yang dicintai. Tahap ini adalah tentang menerima bahwa kematian adalah realita permanen dan belajar untuk menjalani hidup dengannya. Dalam menentang norma baru ini, pada awalnya banyak orang ingin mempertahankan kehidupan seperti sebelum kenyataan berubah. Namun, melalui penerimaan kita melihat bahwa kita tidak dapat mempertahankan masa lalu secara utuh. Kehidupan telah selamanya berubah dan kita harus menyesuaikan kembali.

\section{Cognitive Function of 16 Personalities (Myers-Briggs)}

Fungsi kognitif adalah istilah teknis untuk cara seseorang memproses informasi dan mengambil keputusan terhadap situasi yang terjadi dalam hidupnya berdasarkan pada kepribadiannya. Setiap tipe kepribadian memiliki empat (dari delapan kemungkinan) fungsi kognitif, yang mereka gunakan dalam urutan tertentu. (Priebe, 2015). Mengidentifikasi fungsi mana yang kita gunakan beserta urutannya adalah cara paling akurat untuk mengetahui diri sendiri atau orang lain. Secara keseluruhan, Anda memiliki satu fungsi persepsi ekstrovert, satu fungsi persepsi introvert, satu fungsi penilaian ekstrovert dan satu fungsi penilaian introvert. Keempat fungsi tersebut dibagi menjadi empat fungsi mendetail, antara lain; fungsi intuitif, fungsi penginderaan, fungsi berpikir dan fungsi perasaan. (Hayes, 2017)

\section{Manipulation of Emotion}

Dalam konteks neurobiologi, emosi adalah sebuah kompleksitas yang muncul akibat suatu stimulus, baik dari luar maupun dalam tubuh, di mana stimulus tersebut mengaktifkan beberapa sistem saraf. Emosi hadir dari tiga hal utama, yaitu; sistem pendorong, sistem saraf, dan aksi yang mencerminkan emosi. Beberapa stimulus atas emosi berkaitan erat dengan penginderaan 
kita secara visual, penciuman, pendengaran, perasa, dan peraba. (Damasio, 2011). Untuk sampai ke tahap manipulasi emosi, ada beberapa hal mendasar yang perlu diketahui terkait sistem kerja otak manusia yang disebut pattern recognition. Pattern recognition adalah situasi ketika otak merekam suatu kejadian yang pernah kita alami secara langsung dan menghasilkan emosi tertentu; di mana saat ada kejadian serupa terjadi, otak kita merespon kejadian tersebut dengan mempelajari emosi yang terbentuk dari kejadian lampau (Krause, 2017).

\section{METODE}

Terdapat dua metode utama yang digunakan dalam penelitian ini, antara lain:

- Metode Korelasional: Penelitian ini melibatkan tindakan pengumpulan data guna menentukan hubungan dan tingkat hubungan antara dua variabel atau lebih. Variabelvariabel tersebut akan membentuk sebuah sistem berskala kecil.

- Metode Simulasi: Penelitian ini bertujuan untuk mencari gambaran melalui sebuah sistem berskala kecil atau sederhana (model), di mana pada model tersebut akan dilakukan manipulasi untuk mendorong respon yang dituju.

\section{DISKUSI DAN HASIL}

Pada skema di atas, dapat dilihat sistem kerja otak manusia dalam merekam kejadian pada hidupnya. Sebuah situasi cenderung memiliki stimulus baik dari dalam maupun luar diri kita. Stimulus memunculkan beberapa tanda yang menandai situasi tersebut. Tanda yang muncul dari situasi tersebut akan menghasilkan respon - salah satu respon yang diri kita berikan terhadap suatu kejadian adalah emosi. Sistem berskala kecil yang menghasilkan respon berupa emosi ini dapat diinterupsi dengan melakukan manipulasi terhadap respon yang dituju melalui arsitektur sebagai stimulus.

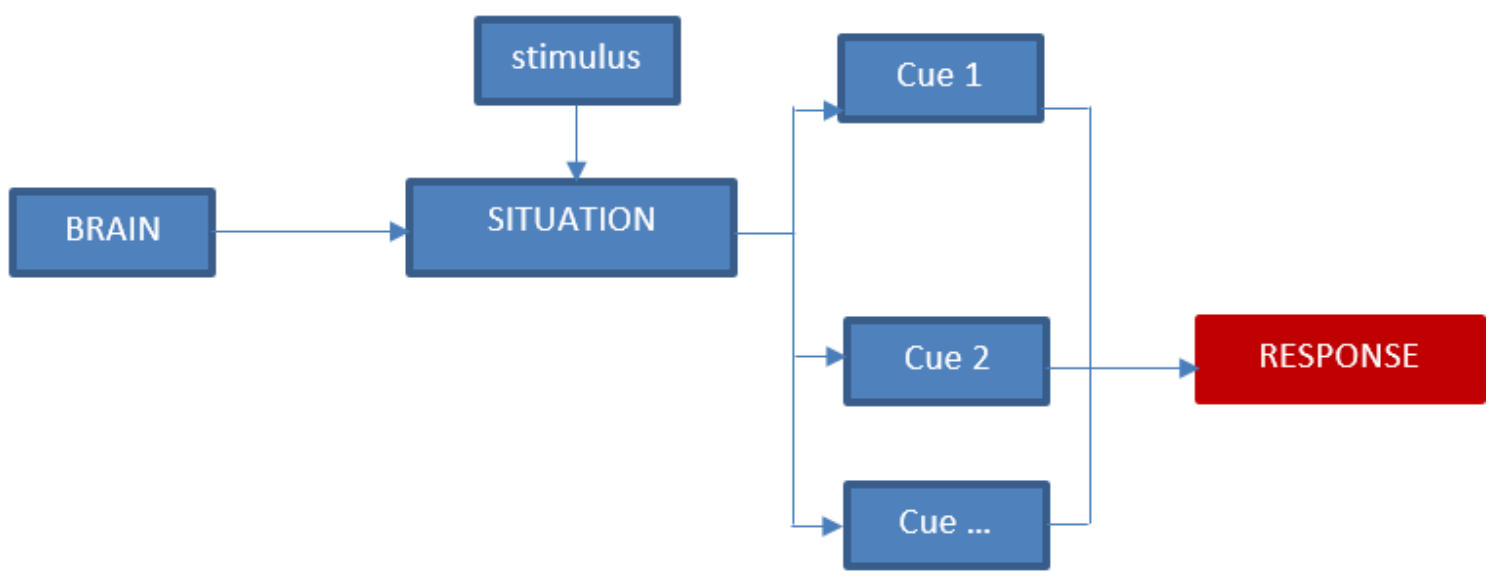

Gambar 1. Skema Kerja Otak Manusia terhadap Situasi

Sumber: Krause, 2017 


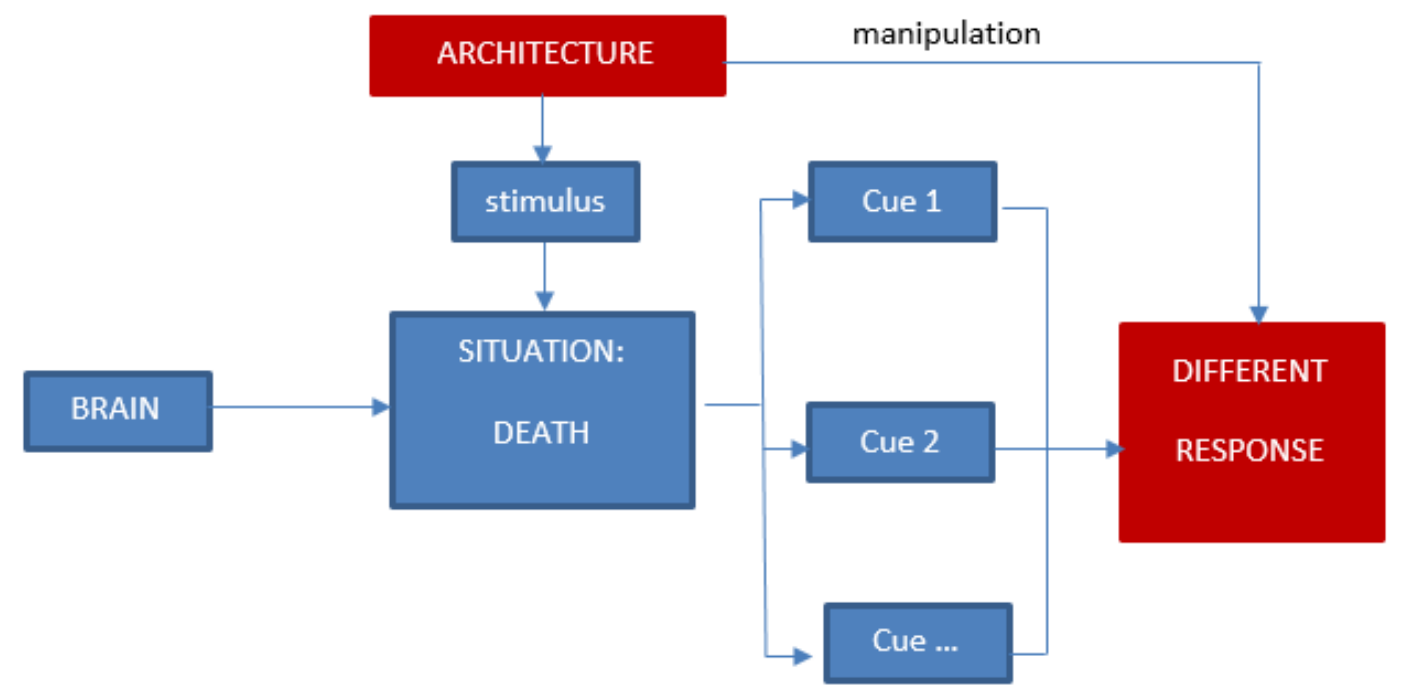

Gambar 2. Hipotesa Skema Kerja Otak Manusia terhadap Situasi dengan Manipulasi Emosi oleh Arsitektur

Apabila dikaitkan dengan tujuan proyek ini dalam menjawab redefinisi kematian, peran arsitektur adalah sebagai jangkar untuk memanipulasi emosi manusia terhadap kematian. Dalam memanipulasi emosi, arsitektur berkorelasi dengan ilmu psikologi dalam penciptaan ruang-ruang terapi secara personal dengan mempertimbangkan aspek; proxemics, psikologi warna, dan psikologi cahaya.

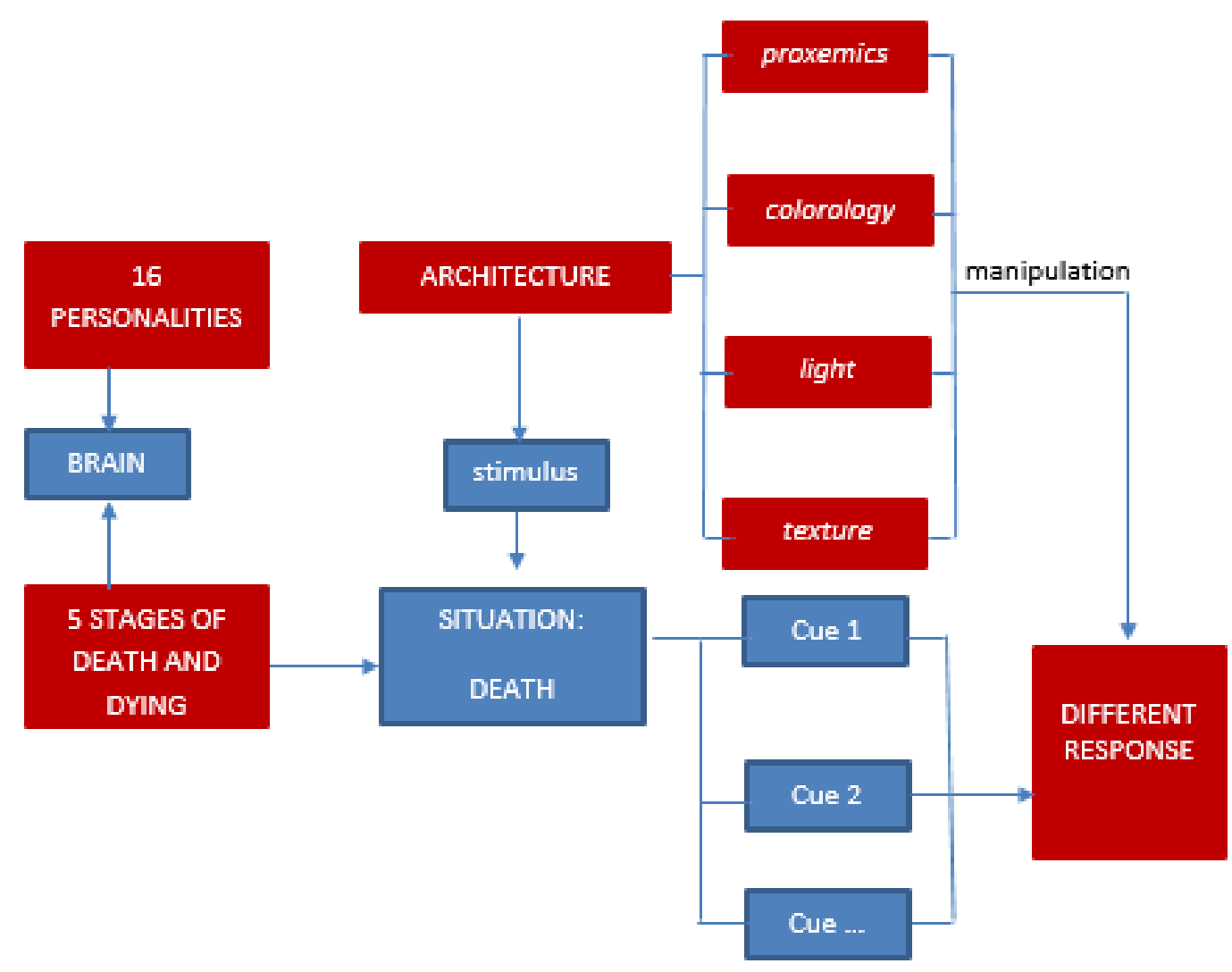

Gambar 3. Hipotesa Skema Kerja Otak Manusia terhadap Situasi dengan Manipulasi Emosi oleh korelasi Arsitektur dan Psikologi 
Terdapat 16 kepribadian dengan fungsi kognitif yang berbeda, di mana dalam fungsi kognitif tersebut, setiap orang memiliki stimulus dan respon yang berbeda terkait 5 tahapan kematian. Untuk itu pembentukan ruang secara arsitektur akan mengacu pada; tipe kepribadian, tahapan kematian, stimulus arsitektur melalui program terapi melalui warna, cahaya, tekstur, dan aroma, serta jarak interaksi manusia (proxemics).

Proyek ini akan menjadi sebuah proyek sosial dengan sistem pendanaan oleh donator dan pemerintah, serta bekerjasama dengan komunitas sosial yang memiliki perhatian khusus terhadap kasus kematian di Indonesia. Target konsumen dari proyek ini mencakup berbagai rentang usia dan golongan untuk mendukung keberlangsungan proyek ini. Adapun skema kerja hasil temuan tersebutlah yang diaplikasikan ke dalam desain perancangan diawali dengan implementasi pada alur aktivitas dan operasional dalam proyek seperti yang tertera dalam gambar berikut.

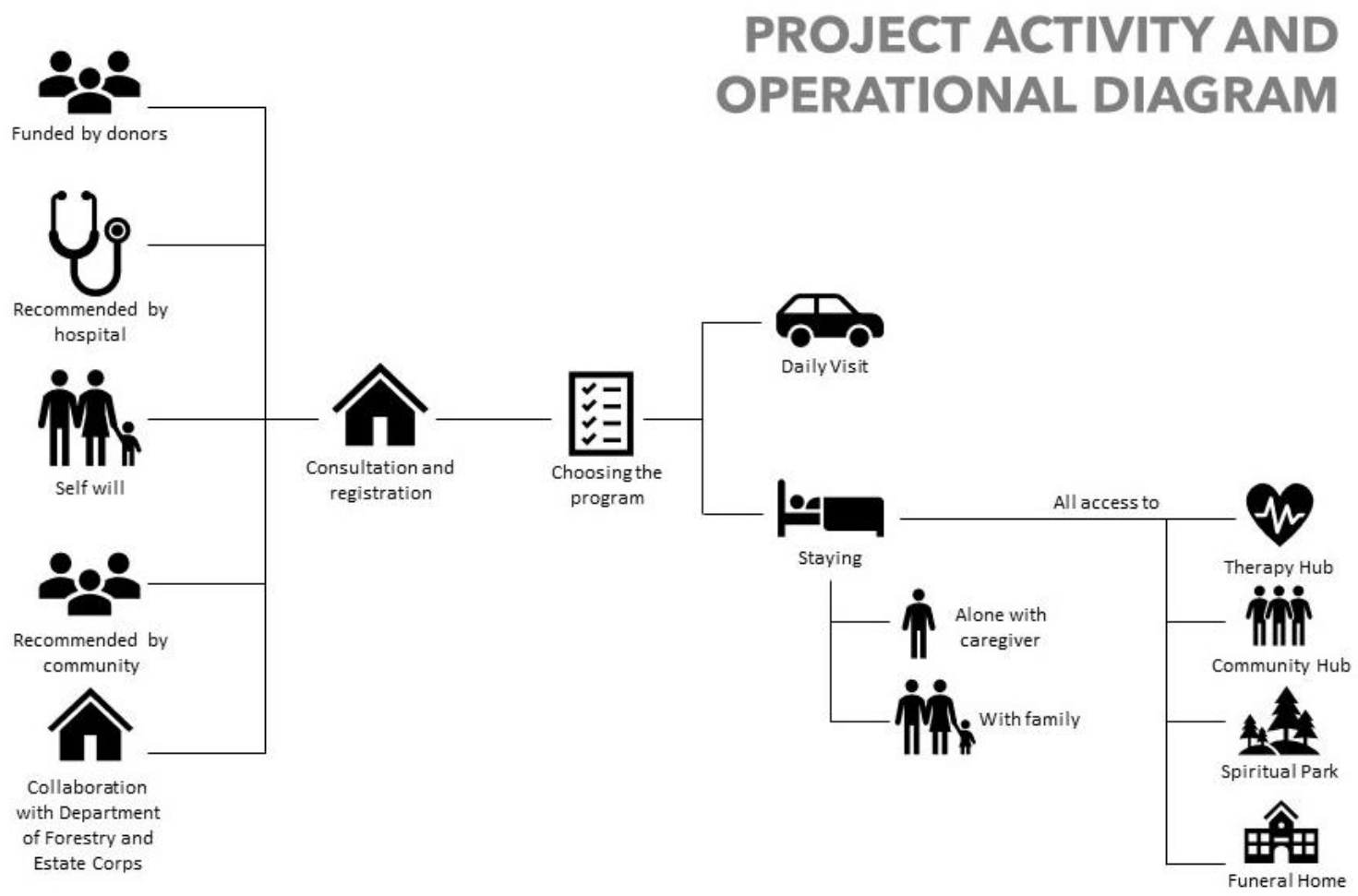

Gambar 4. Aktivitas pada proyek dan diagram operasional

Sumber: Penulis, 2019

Setelah melakukan riset dan analisa aktivitas yang akan berlangsung pada proyek, proses perancangan dimulai dengan melakukan sketsa potongan suasana pada setiap zona yang akan di desain dengan mempertimbangkan pengalaman ruang dan dampak psikologis pada pengguna untuk dapat memanipulasi emosi secara arsitektural, seperti yang tertera dalam gambar di bawah ini. 


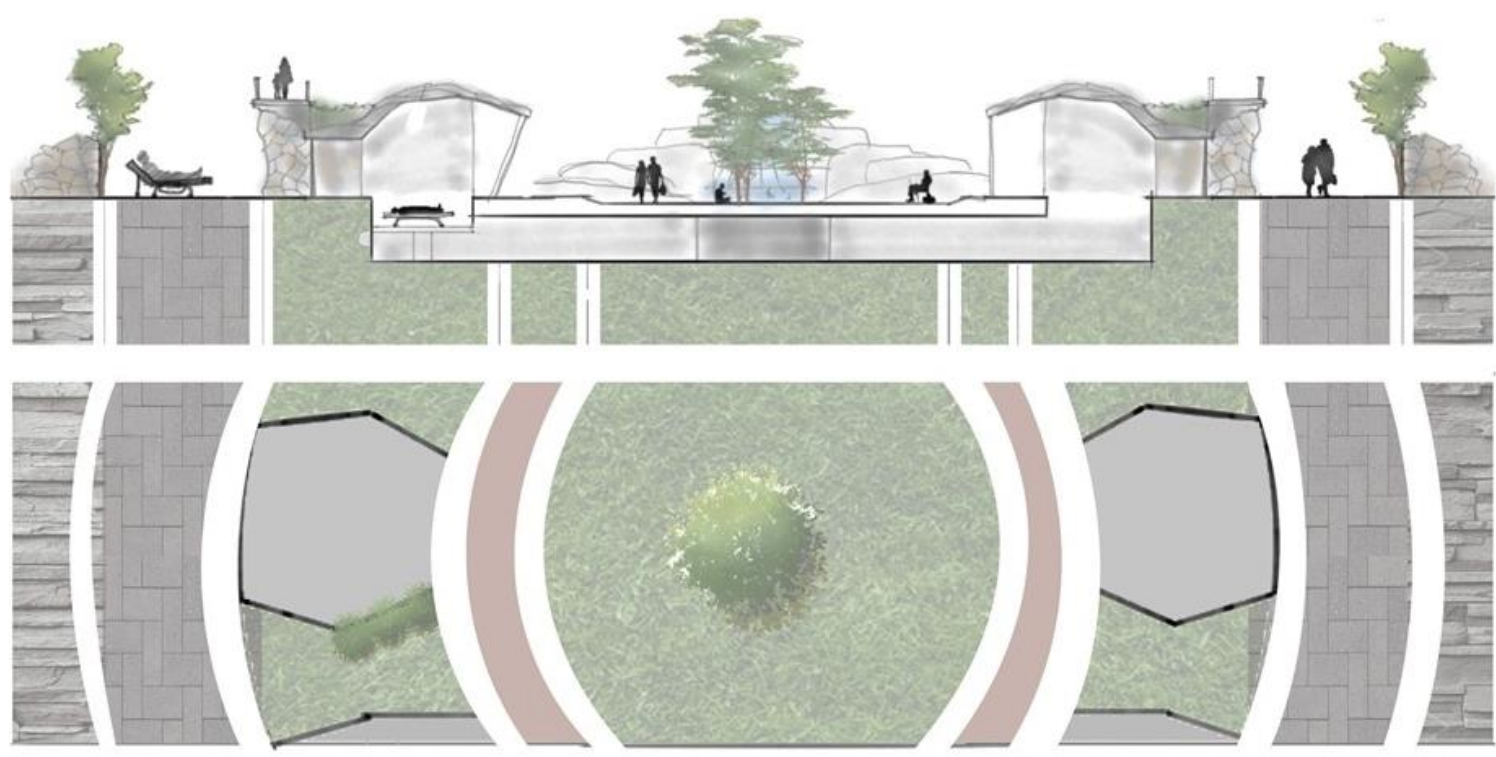

Gambar 5. Sketsa aktivitas dan suasana pada unit hospice yang dirancang

Sumber: Penulis, 2019

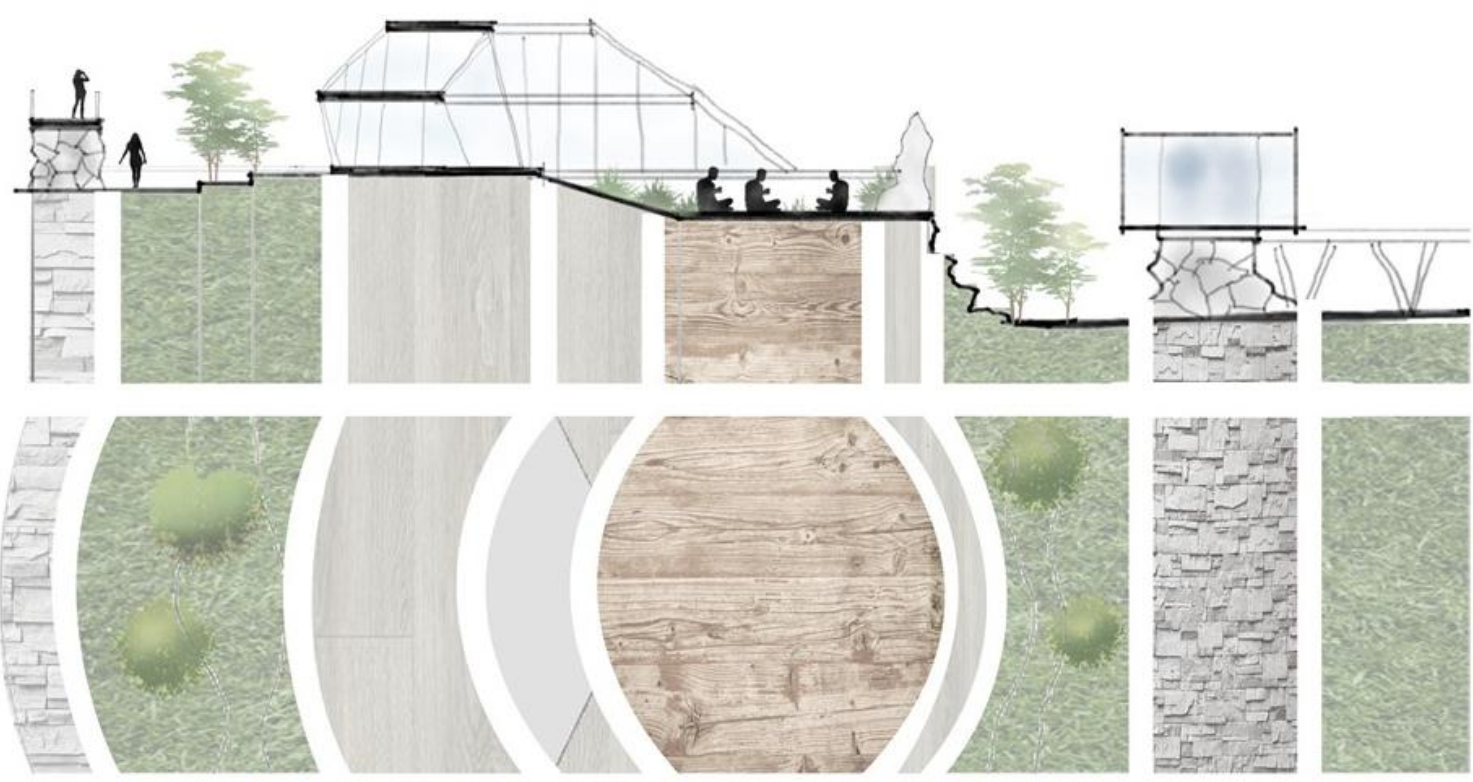

Gambar 6. Sketsa aktivitas dan suasana pada Spiritual Park

Sumber: Penulis, 2019

Setelah melakukan sketsa aktivitas dan suasana, pada beberapa titik di zona yang ditentukan, maka dihasilkanlah gambar perancangan sebagai berikut disertai potongan suasana pada titik yang ditentukan. 


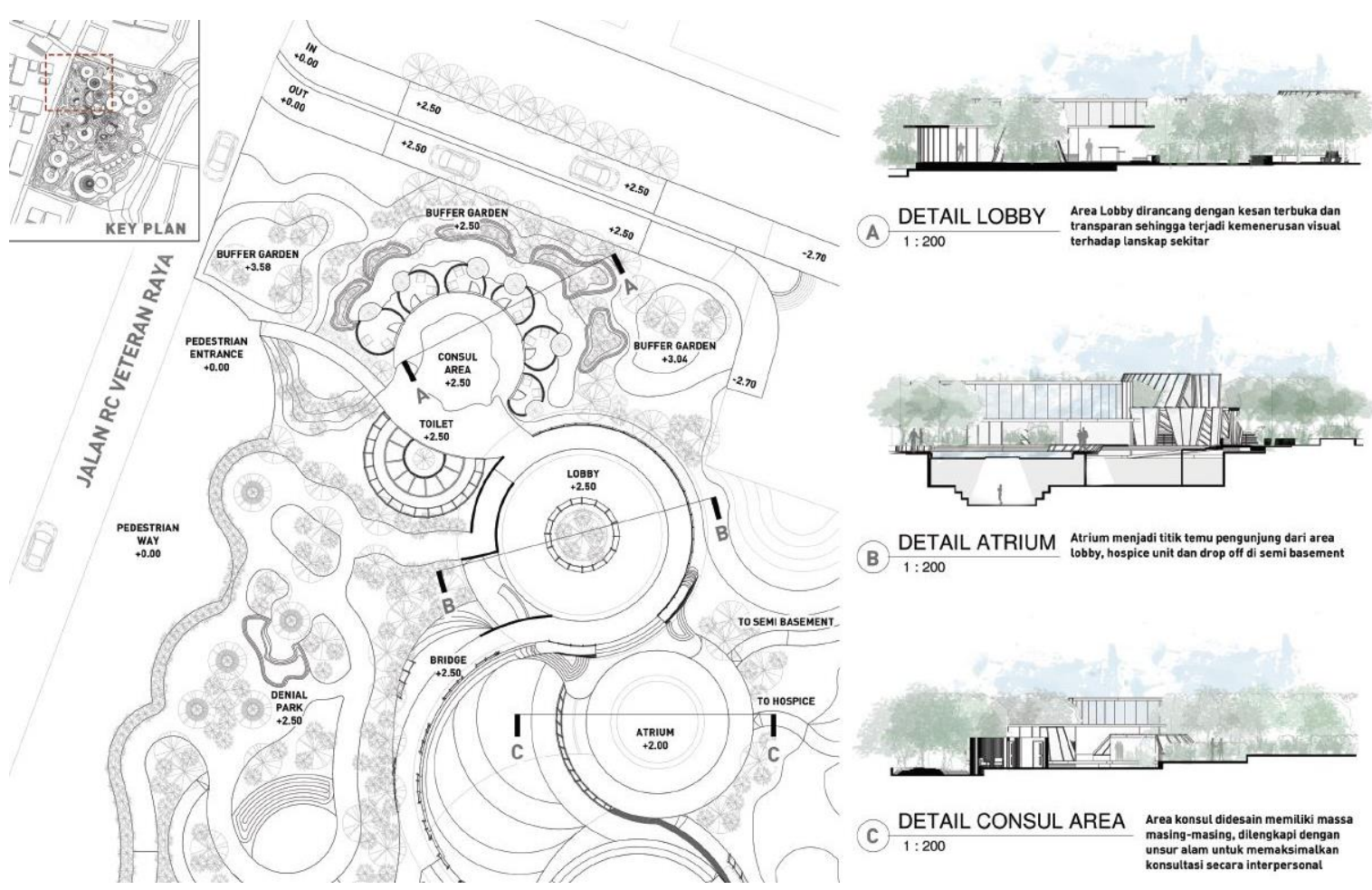

Gambar 7. Denah Lantai Dasar Bagian A

Sumber: Penulis, 2019
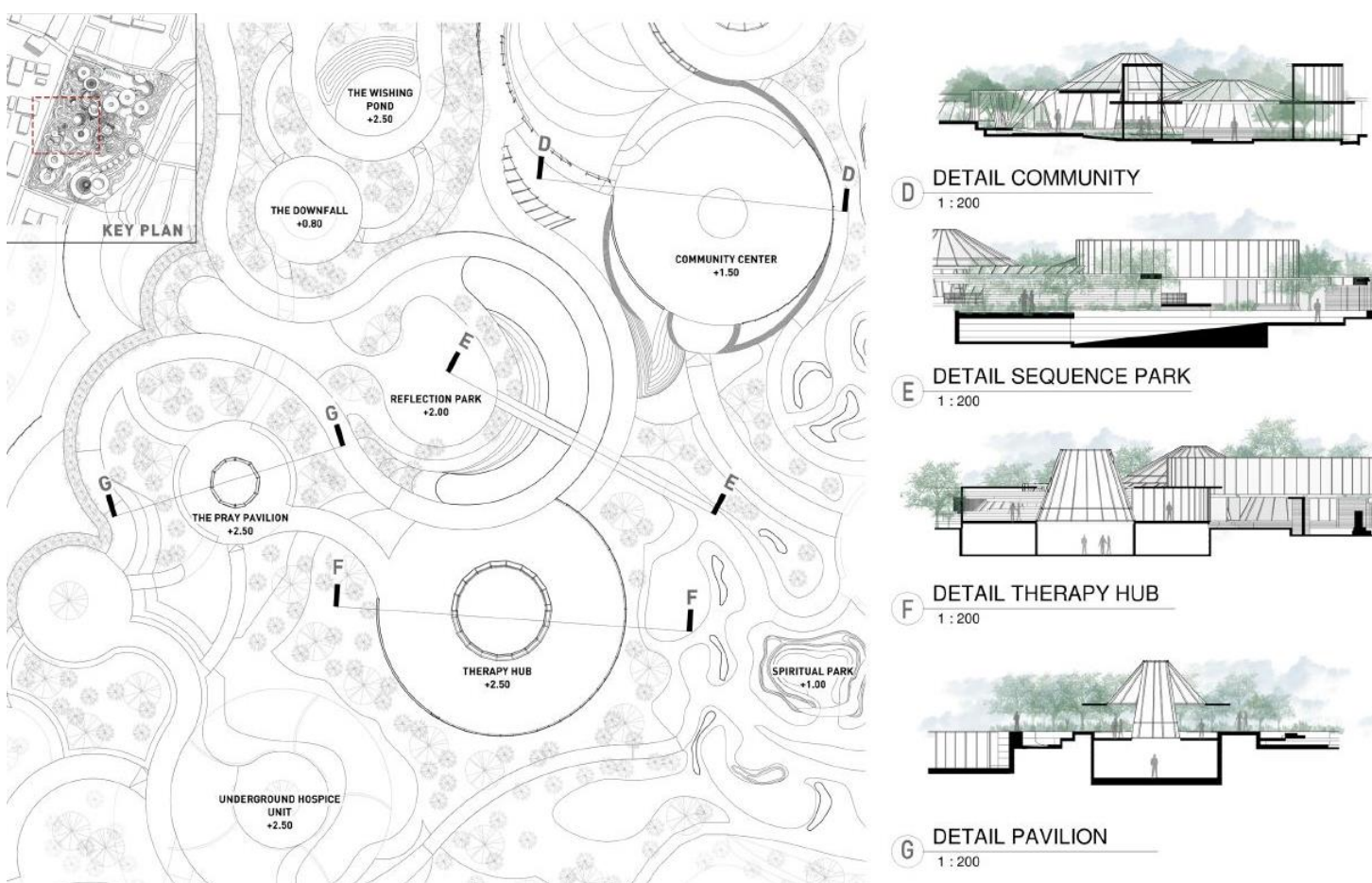

DETAIL COMMUNITY

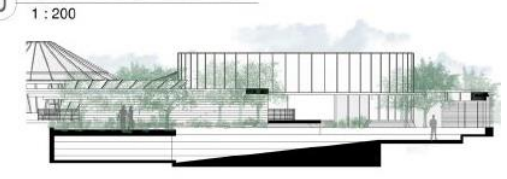

E DETAIL SEQUENCE PARK

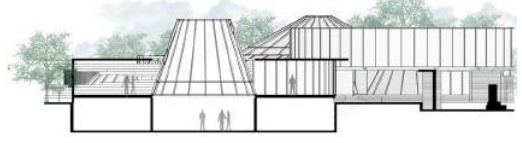

F DETAIL THERAPY HUB

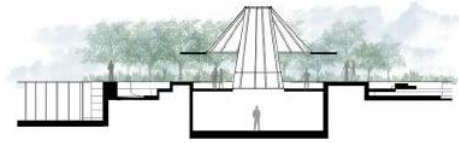

G DETAIL PAVILION

Gambar 8. Denah Lantai Dasar Bagian B

Sumber: Penulis, 2019 


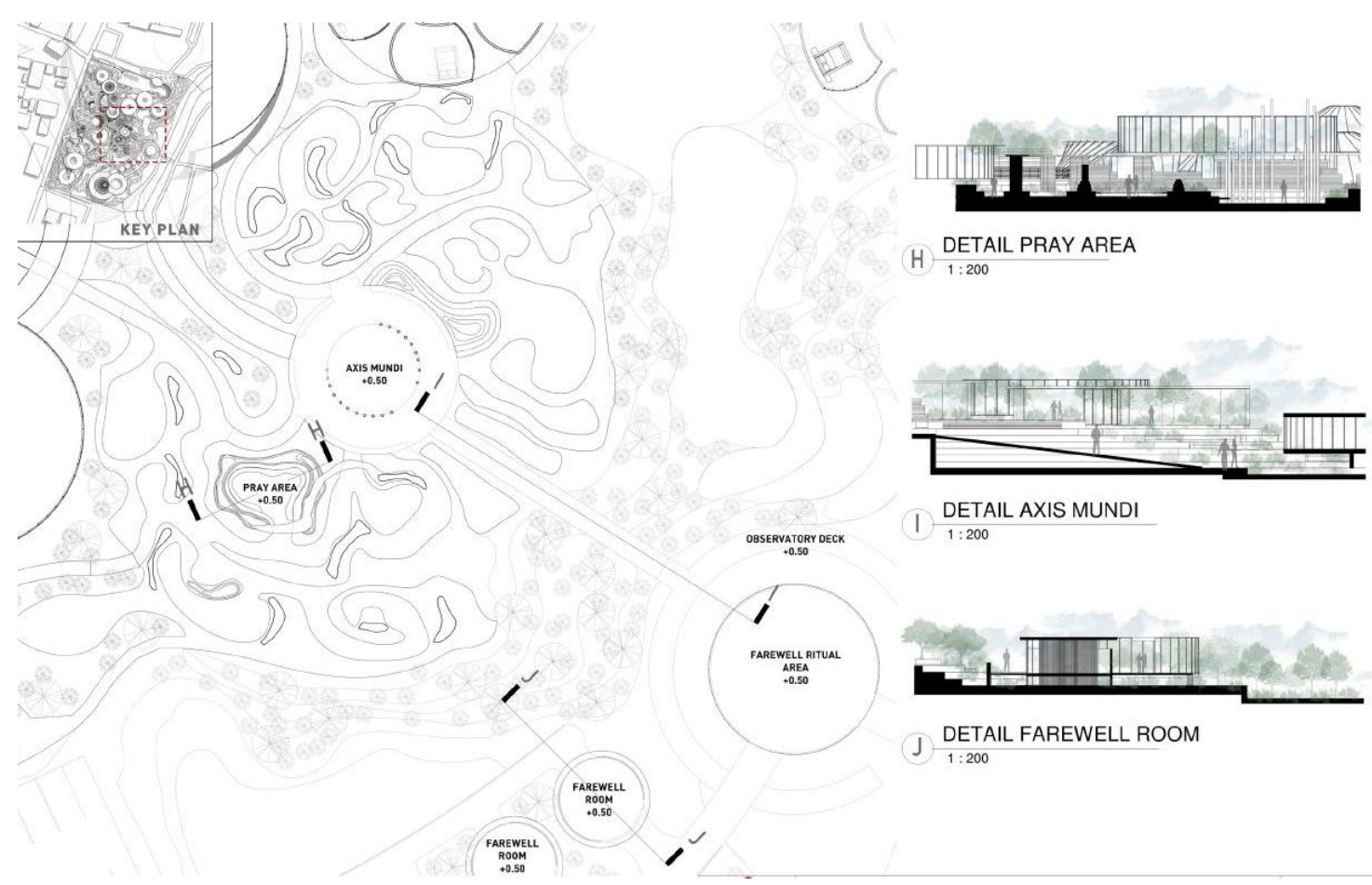

Gambar 9. Denah Lantai Dasar Bagian C

Sumber: Penulis, 2019
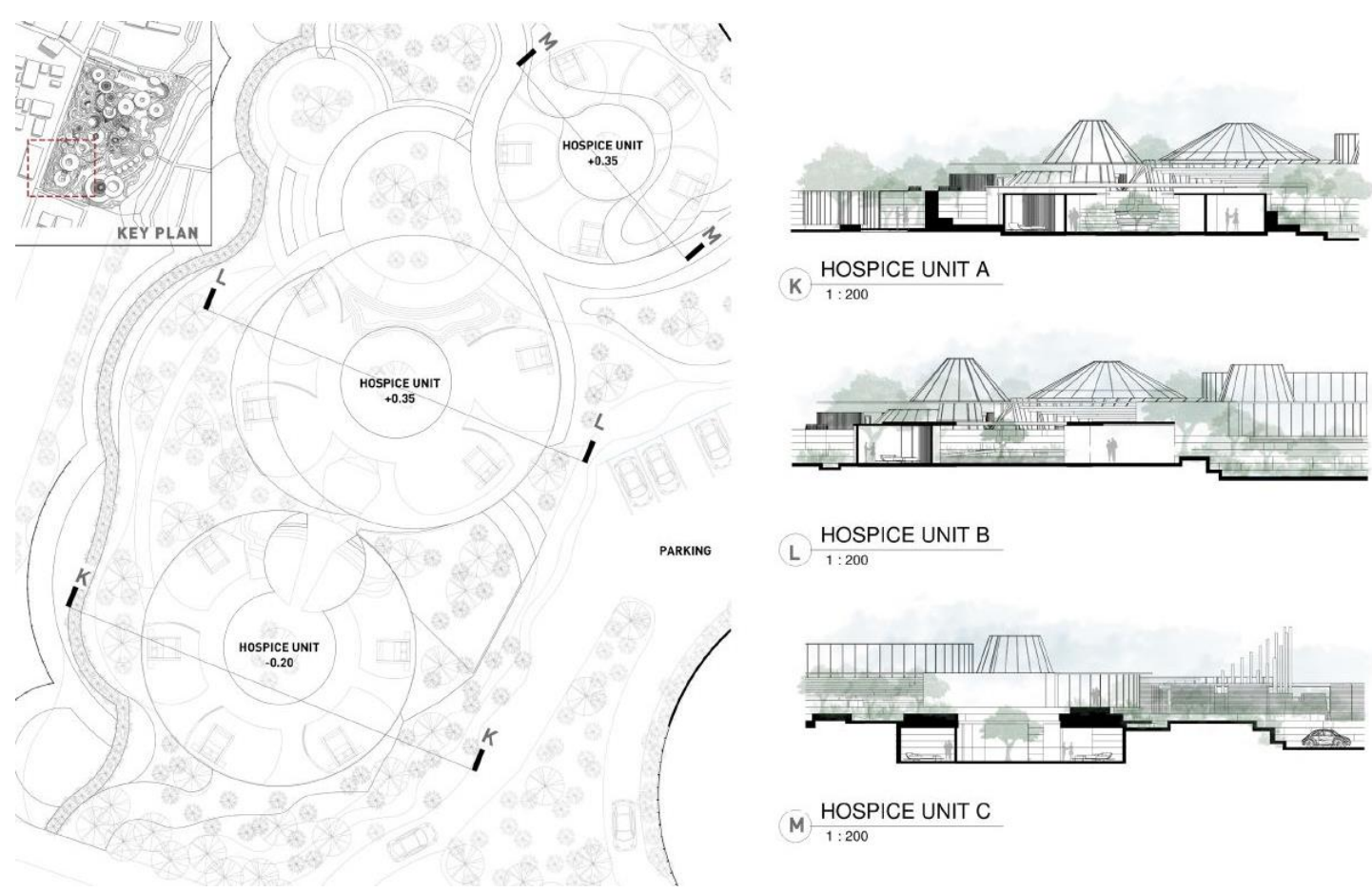

K $\frac{\text { HOSPICE UNIT A }}{1: 200}$

Gambar 10. Denah Lantai Dasar D

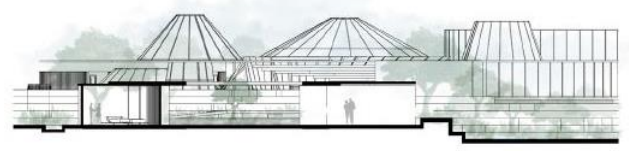

L) HOSPICE UNIT B

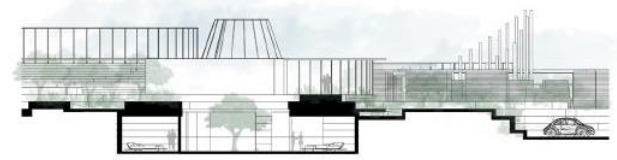

M HOSPICE UNIT C

Sumber: Penulis, 2019 


\section{KESIMPULAN DAN SARAN}

Pada akhir penelitian ini, dapat ditarik beberapa kesimpulan, antara lain; dalam mewadahi proses kematian masyarakat di kota, arsitektur dapat menghadirkan program psikoterapi yang mampu menjadi stimulus dalam memanipulasi emosi negatif masyarakat terhadap kematian; dengan adanya manipulasi terhadap emosi negatif, masyarakat dapat merasakan pandangan positif terkait proses kematian; pada akhirnya dengan adanya pandangan positif, masyarakat akan memaknai kematian sebagai momen spesial secara personal dan dengan orang terkasih melalui wadah arsitektur. Kesiapan masyarakat dalam menghadapi kematian, secara tidak langsung akan meningkatkan taraf kebahagiaan dalam skala kota yang turut menyumbang pada keberhasilan program ini dalam jangka panjang.

\section{REFERENSI}

Damasio, A. (2011). Neural Basis of Emotions. Scholarpedia. Retrieved from Scholarpedia.

Hayes, D. N. (2017). Understand Psychology. United Kingdom: John Murray Learning.

Krause, T. (2017, October 17). Mastering Our Own Minds. Retrieved from TEDxFryslan: https://tedx.frl/event/tedxfryslan2017/talk/timon-krause/

Kubler-Ross, E., \& Kessler, D. (2007). On Grief and Grieving. Scribner.

Priebe, H. (2015, June 10). An Intro to Cognitive Functions. Retrieved from Thought Catalog: https://thoughtcatalog.com/heidi-priebe/2015/06/if-youre-confused-about-your-myers-

briggs-personality-type-read-this-an-intro-to-cognitive-functions/ 